\title{
PIOTR BORUCKI
}

(Białystok)

\section{PRZEMIJALNOŚĆ JAKO ZAPOWIEDŹ USPRAWIEDLIWIENIA LEOPOLDA STAFFA ROZWAŻANIA O RZECZACH OSTATECZNYCH}

20 marca 1901 roku, dwudziestotrzyletni wówczas Staff, w liście skierowanym do Zenona „Miriama” Przesmyckiego pisał między innymi:

Posyłam dla „Chimery” cykl Pieśni szaleńca i fragment oktawami. Poza tym nie mam na razie zbyt wiele $\mathrm{w}$ tece, ponieważ od pół roku przeszło pracuję nad utworem większych rozmiarów, który pochłania wszystkie moje siły i cały czas wolny. Tercyny i załączone do niniejszego listu oktawy są fragmentami tej całości. Jeżeli Pieśni szaleńca do „Chimery” się nadadzą, to pragnąłbym bardzo, ażeby drukowane były w jednym numerze, bo mimo odrębności każdego są one związane po części ze sobą wewnętrznie.

Z dawnych nadesłanych „Chimerze” wierszy moich znajduje się jeszcze w tece Szanownego Pana Deszcz jesienny i Bladej dziewczynie, które jeszcze drukowane nigdzie nie były... ${ }^{1}$

Dzisiaj wiemy już, że owa całość, o której wspominał autor Snów o potędze, przybrała postać wydanego dwa lata później tomu poetyckiego Dzień duszy², w którym również, aczkolwiek w zmienionej formie, znalazł się wspomniany wyżej cykl Pieśni szaleńca. Co innego jednak, w cytowanym przed chwilą fragmencie listu, zwraca uwagę, a mianowicie to gorące zapewnienie samego Staffa, iż jego

\footnotetext{
1 Leopold Staff. W kregu literackich przyjaźni. Listy, opr. J. Czachowska I. Maciejewska, PIW, Warszawa 1966, s. 302.

2 Leopold Staff, Dzień duszy, Instytut Wydawniczy Biblioteka Polska, Warszawa 1922. Jest to czwarte $\mathrm{z}$ kolei wydanie tomiku, z którego czerpię cytowane w niniejszej pracy fragmenty wierszy Staffa.
} 
utwory sa (...) zwiazzane po części ze soba wewnętrznie. Wyznanie to stanowić może klucz do głębszego zrozumienia lwowskiego okresu jego twórczości, a zarazem domaga się od czytelnika, aby w procesie lektury i interpretacji wierszy tam zawartych starał się odnaleźć wewnętrzne, choć niewidoczne, nici łączące pojedyncze teksty w obszerniejszą znaczeniowo wypowiedź. I o ile poeta sprawę tę nam ułatwia, przydzielając po prostu poszczególne utwory do odrębnych części tomu ${ }^{3}$, to wyszukanie dominanty każdej z nich powierza już naszej wrażliwości.

Jest jednak coś, co pozwoliło Staffowi nadać wszystkim owym częściom spójny i wewnętrznie uporządkowany charakter, co w stosunku do nich stanowi nadrzędną formułę każdego aktu odczytania - jest nią oczywiście zdumiewający w swym znaczeniu tytuł: Dzień duszy. O ile bowiem dzień, stanowiący jednostkę linearnie pojmowanego czasu, będący zarazem niejako narzędziem periodyzacji, przywołuje takie jego rozumienie, iż biorąc się z nieskończoności (nicości) ku nieskończoności zmierza, o tyle stwierdzenie to stoi jawnie w sprzeczności z czystą bezczasowością, wiecznością, do której przynależy nieśmiertelna dusza. Czymże zatem miałby być ów Dzień duszy? Powiązaniem ze sobą, niedajaccych się przecież pogodzić, elementów? Poetycką metaforą? Marzeniem? Czy raczej wpisaniem sensu ludzkiej egzystencji, w przeciwieństwie do tradycyjnie pojmowanej historii i przemijalności, w nowe, pełniejsze i prawdziwsze ramy? Akceptacją obydwu współwystępujących porządków? Metahistorią?... ${ }^{4}$

Pozostawmy jednak na chwilę zapoczątkowane tu rozważania, by na samym ich wstępie poczynić jeszcze jedną, istotną refleksję. Otóż wiersze dawne, o których także pisał poeta, a wśród nich najbardziej chyba dziś znany tekst Staffa, Deszcz jesienny, znalazły się w najdłuższej części wydanego w 1903 roku zbioru. Zarazem tytuł owego istotnego „rozdziału” może stać się bardzo mylący, ponieważ Przez mrok jest raczej w swej wymowie przeciwieństwem uciążliwego i rozpaczliwego przedzierania się do wszechogarniającego światła wiedzy pewnej i raz na zawsze zdobytej, co może sugerować użyte w tym miejscu sformułowanie. Kroczenie ową ścieżką w Dniu duszy i jednoczesne przechodzenie Przez mrok Tajemnicy

3 W Dniu duszy będą to odpowiednio: Z sonetów, Luźne kartki, Pieśni szaleńca, Przez mrok, Pocalunki, Matka, Dzień pracy, Szczęście wiosenne, Poludnie wlóczęgi, Bogowie.

4 Tak pojęcie to, wyjaśnia ks. prof. Wacław Hryniewicz: „Wprowadzone przez S. Bułgakowa i podjęte przez innych teologów prawosławnych pojęcie metahistorii pozwala powiązać ze sobą tajemnicę czasu i wieczności. W stosunku do porządku czasowego metahistoria jest rzeczywistością umożliwiającą styk z rzeczywistością eschatyczną. To ona właśnie nadaje wydarzeniom czasowym ostateczne odniesienie i znaczenie; wprowadza w nie wymiar wieczności. Jest swego rodzaju świętą przestrzenią, w której dokonują się wydarzenia czasowe. W tym sensie można by ją nazwać wszechogarniającą czasoprzestrzenią (pojęcie zaczerpnięte z nauk ścisłych), umożliwiającą dokonywanie się wydarzeń czasowych w ich wymiarze eschatycznym. Tego rodzaju intuicja wskazuje na względność czasu i wszelkiej chronologii empirycznej. Czas nie jest wartością samoistną, absolutną i przeciwstawną wieczności"; W. Hryniewicz OMI, Nadzieja zbawienia dla wszystkich. Od eschatologii lęku do eschatologii nadziei, Verbinum, Warszawa 1990, s. 47. 
nie ma w sobie nic z naukowej pewności, przynależne jest raczej sferze wiary, wewnętrznych przekonań i nigdy niesprawdzalnych twierdzeń, które, z drugiej strony, nie tracą przez to nic ze swej mocy wyrazu. Przyjęte być zatem mogą, tak jak wszystkie zresztą próby rozstrzygnięć kwestii ostatecznych, jedynie w postawie ufności, właściwej wnętrzu człowieka poszukującego nie gotowych odpowiedzi ale zrozumienia istoty nierozstrzygalnego przecież problemu. Czy doświadczenie mroku może być tutaj jakąś wskazówką? ${ }^{5}$

I ostatnie już, krótkie zastrzeżenie: u podstaw tak skonstruowanej metaforyki, pozwalającej możliwie w pełni uchwycić sens opisywanych przez poetę zjawisk, leży pojęcie czasowości wraz ze wszystkimi jej konsekwencjami: nieuchronnością, koniecznością przemijania i realnością dokonujących się w tym czasie zmian. Zatem Staff, wygłaszając swe poetyckie tempus fugit, wcale nie rezygnuje z racjonalizmu, wręcz przeciwnie - autor Snów o potędze zdaje się mówić: to rozum umożliwia wiare, i jest $\mathrm{w}$ tym twierdzeniu coś z istoty chrześcijaństwa...

\section{$* * *$}

Spróbujmy się zatem bliżej przyjrzeć wędrówce, której odbycie proponuje nam młody poeta. Pierwszym jej, a zarazem najbardziej kluczowym, wyznacznikiem jest owo silne przeświadczenie nieuchronności przemijania. Czas, gdyby go sobie spróbować wyobrazić, jest tu linią prostą, ale czy na pewno jedyną? Wszak wahadło, które zdaje się być sercem zegara, miota się w sprzecznych ruchach, napędzając swym rozpaczliwie monotonnym taktem wskazówki, wyznaczające już całkiem inny porządek istnienia:

Jam jest wieczne wahadło, co wolą sprężyny

Tajemnej w dwóch odwrotnych dróg ciskane sprzeczność,

Kołysze się nad bezdnią otchłannej głębiny

A w jednostajnym chodzie mym przeciaga wieczność.

Z niebytu chwilę rodzę, a już w nicość pada...

$\mathrm{W}$ moim miarowym szepcie drżą dziwne agonje:

To czas usypiającą melodią spowiada

Na śmierć swoje przeciągłe, długie monotonje...

5 Warto w tym miejscu zwrócić szczególną uwagę na tekst, którego ze względu na ograniczenia związane $\mathrm{z}$ tematem niniejszej pracy nie przedstawiam w toku wywodu. Jest to mianowicie wiersz Światla ukryte, który należy, nota bene, do tego samego cyklu, co Deszcz jesienny. Na ile stanowi on interesujący kontekst, w nawiązaniu do poczynionej przez Nowosielskiego, w książce Mój Chrystus, refleksji o oczyszczającej potrzebie doświadczenia katastrofy, może ocenić już sam Czytelnik; zob. Z. Podgórzec, Mój Chrystus. Rozmowy z Jerzym Nowosielskim, Wydawnictwo Łuk, Białystok 1993. 
Wysiłkiem coraz nowym wciąż jedną zdobywam

Przestrzeń, co w mem wahaniu wieczyście umiera...

Bo każdym nowym ruchem dawny odwoływam,

Zaprzeczam... Bieg mój każdy stare szlaki ściera...

Zamknięty w kolej swego wiecznego spętania,

Co tym ruchem zdobędę, następnym utracam...

A jednak me codzienne, przeciwne wahania,

To ciągła droga naprzód. - Ja nigdy nie wracam!

$(\ldots)$

I złudna tarcz zegaru rdzą zżarta się kruszy

I spada w niemą nicość otchłannej ciemnicy...

A ja waham niezmiennie, wahadło wśród głuszy,

Bom zawieszony w dłoni wielkiej Tajemnicy...

Cisza...Czas siwy senną melodją spowiada

Na śmierć swoje przewlekłe, nudne monotonje

$\mathrm{Z}$ wieści, że jedna zawsze jest święta i blada

Godzina... Ja wahadło wieczne - Wieczność dzwonię... ${ }^{6}$

Od czegóż jednak zacząć opis przeczucia Tajemnicy? Zawsze bowiem, kiedy stajemy wobec tak wielkiego bogactwa myśli, rodzi się obawa, by nie uronić z nich ani cząstki. Przychodzi nam zatem jeszcze raz zawierzyć samemu poecie: Problemów się nie rozwiazuje. Problemy się przeżywa... ${ }^{7}$

Znamienna jest ta personalistyczna perspektywa, z jaką Staff stawia problem, cały wiersz utrzymany jest bowiem w konwencji wyznania. Nasuwa się więc od razu oczywiste pytanie: czy zasadne jest, w toku podjętej interpretacji, symboliczne zrównanie człowieka z mówiącym wahadłem? Myślę, że taki zabieg byłby całkowicie uprawniony - przy oczywistym założeniu, z drugiej strony, możliwości wielu, współistniejących ze sobą odczytań. Ingardenowskie spojrzenie na tekst jako na kilka, wzajemnie się uzupełniających warstw, tworzących przez to spójną (choć często wieloznaczną) całość, stanowi dla tej operacji dodatkowe wytłumaczenie ${ }^{8}$.

Niezwykle silne zaakcentowanie personalizmu jest także dość wyraźnym sygnałem, iż poruszany w tekście problem dotyka bezpośrednio każdego z nas, a jego

\footnotetext{
6 Leopold Staff, Wahadto, w: Dzień duszy, op. cit., s. 107-109; w przywołanym tu wierszu zachowano oryginalną pisownię.

7 Leopold Staff, Dziewięć muz, PIW, Warszawa 1958, s. 55.

8 Por. R. Ingarden, Szkice z filozofi literatury, Kraków 2000.
} 
osobliwe ujęcie dodatkowo świadczyć może o konfesyjnym charakterze tej wypowiedzi. Któż bowiem, przyjąwszy racjonalne przesłanki o zanurzeniu ludzkiej egzystencji w linearnie pojmowanym czasie, ośmieli się zaprzeczyć słowom: tylko otchtań nade mna $i$ bezdeń pode mna, przywodzącym na myśl wyznanie Pascala? Z nicości wynurzeni zmierzamy ku otchłani, i przeświadczenie owo, przeświadczenie o realnej obecności i nieuchronności przemijania, której wszyscy podlegamy, stanowić będzie zarazem punkt wyjścia do naszych dalszych rozważań.

W doświadczeniu przemijalności kryje się przecież pewien paradoks, któremu Staff konsekwentnie daje wyraz w całym tekście. Wszak obok ulotności następujących po sobie chwil, znajdujemy takie oto określenie: wieczne wahadło. Wyjaśnić przy tym należałoby od razu, iż nie może tu chodzić o banalną z gruntu prawdę, zawierającą się w twierdzeniu: wieczne w upływie czasu jest to, że czas płynie wiecznie. Paradoks ten, wyrażony w hermetycznym i strukturalnie idealnym obrazie poruszającego się w dwukierunkowym ruchu wahadła, jest bowiem jednoczesną zapowiedzią objawienia Tajemnicy, której istnienie bierze swój początek właśnie z tej wewnętrznej sprzeczności: Jam jest wieczne wahadło, co wola sprężyny / Tajemnej w dwóch odwrotnych dróg ciskane sprzeczność. Jednakowoż owa niezgodność prowadzi do zaskakującej zapowiedzi: A w jednostajnym chodzie mym przeciaga wieczność i w tym momencie dochodzimy do sedna problemu, ponieważ poszczególne obrazy, pojawiające się po zaistniałej już deklaracji, są jedynie różnymi wariantami tej samej wypowiedzi.

Chodzi zatem o wieczność zgoła innego rodzaju, w jej - jak to już wcześniej wykazaliśmy - personalistycznym wymiarze. Wieczność zatem, której zapowiedzią stają się takie obrazy, jak czas, który w nieustannej agonii chwil spowiada się miarowym odgłosem tykającego zegara; wschód i zachód, gonione ciągle przez obracające się wokół własnej osi wskazówki, a więc będące przez to włączonymi do jednego wymiaru, w którym współistniejąc dopełniają się wzajemnie, tworząc naturalny porządek rzeczy; studnia, której wody życia napełniają się spadającymi kroplami tak, jak godziny dopełniają miary istnienia wszechrzeczy. Jest to zarazem wieczność, której interpretacją stały się opisy w dwóch ostatnich strofach wiersza, wieczność w rozumieniu eschatologicznym.

Okazuje się przecież, iż otchłań, mierzona cisza świętej mądrości niezmordowanego wahadła ${ }^{9}$ przewyższa daleko bardziej swym istnieniem nasze dotychczasowe sądy i wyobrażenia czasu. I złudna tarcz zegaru rdza ż̇arta się kruszy /

\footnotetext{
9 Warto zwrócić uwagę na niezwykłą konsekwencję, z jaką Staff, w większym lub mniejszym stopniu aluzyjności, ukazuje trudno uchwytny moment przechodzenia z wymiaru doczesnego do ostatecznej sfery sacrum, lub jak pokazuje nieuchronne ze sobą powiązanie obu tych elementów, co stanowić może kolejny dowód na ostateczne usprawiedliwienie. Pełniejszy i zarazem bardziej ostry wyraz takim poglądom dał jednak Twórca w innym tekście, o którym mowa będzie za chwilę. Zob. także przypis 5.
} 
I spada w niema nicość otchłannej ciemnicy... Oto dokonał się akt symbolicznego zniesienia dotychczasowego porządku, choć może właściwsze w tym wypadku byłoby użycie innego określenia, a mianowicie: czas się wypełnił. Dopiero teraz jego dwudzielna istota widoczna jest najbardziej, wszak (...) ja waham niezmiennie, wahadło wśród gluszy, / Bom zawieszony w dłoni wielkiej Tajemnicy...

Do czegóż więc prowadzi nas przyjęcie tak rozumianej przemijalności? Jaką Tajemnicę w sobie skrywa? Czym miałoby być wpisane w nią osiągnięcie pełni czasu, jeśli nie czystą bezczasowością i czy przyjęcie takich założeń, miast prowadzić do usprawiedliwienia, nie ukazuje raczej absurdu przemijania? Odpowiedź, którą daje Staff, jest bardzo prosta. Nie ma w sobie nic z naukowej pewności, bo ta domaga się dowodów, a dowodem w tej sprawie jest, paradoksalnie, samo istnienie problemu, ujęte $\mathrm{w}$ zwrotce ostatniej.

Płynność i ulotność są tu jednak najściślej powiązane z trwałością innego rodzaju, do której, poprzez przemijalność, każdy z nas zmierza, którą każdy osiągnie. W jaki więc zatem sposób opisać tę nadchodząca rzeczywistość, czy będzie ona wiecznością zbawienia czy może raczej potępienia; na te pytania poeta dał w $W a-$ hadle odpowiedź częściową i nasze dalsze rozmyślania podążać powinny właśnie w kierunku ukazania w pełniejszym świetle pojawiających się tu intuicji.

\section{$* * *$}

Poprzez długie i niemal w wieczność całą przeciągające się godziny Dnia duszy, których jedyną oznaką mijania były ciche, jednostajne i, same w sobie, sprzeczne ruchy Wahadta, przywodzi nas poeta do zmierzchu - owej pory, gdzie rzeczywistość zatraca swe granice, kontury wyraźnie dotąd widzianych przedmiotów rozmazują się, a świat (czy Przez mrok?) wraca do swej pierwotnej jedności, zanurzając się w Tajemnicę. Nastaje wówczas ten czas, kiedy dużo łatwiej i prościej jest poznawać oczyma wiary. Przychodzą wówczas na myśl słowa św. Pawła, tego, który na czas jakiś stracił swój wzrok: Teraz widzimy jakby w zwierciadle, niejasno; wtedy zaś [zobaczymy] twarza w twarz. Teraz poznaje po części, wtedy zaś poznam tak, jak i zostałem poznany ${ }^{10}$. Kolejny wiersz Staffa jest właśnie taką próbą dojrzenia, mimo niedoskonałości sądów wypowiadanych w tej kwestii, ostatecznego celu ludzkiej wędrówki. Być może także dlatego, miast jednoznacznych i butnych stwierdzeń, przybrał formę, zadawanego Bogu, odważnego pytania?

Jakże mię karać będziesz Panie,

Za grzechy moje i za winy,

Gdy zegar dni mych bić przestanie?

101 Kor, 13, 12. (cyt. za Biblią Tysiąclecia, wyd. Pallottinum, Poznań 1996). 
Minione dnie - to snów głębiny

W nicość rozprzęgłe, próżne czasze,

Niegdyś miodnymi skrzące płyny.

Przewiny nasze, grzechy nasze

To dnie trawione swemi żary,

Aż mrok nicości je opasze.

Każdy grzech w sobie ma rdzeń kary -

A kara grzechom to ich zgłada...

Jak smutny dzień nasz zmierzchem stary!

(...)

Nie stanie grzech mój pod Twym biczem,

Bo niema już dnia grzechu mego.

Przewina moja jest dziś niczem...

Grzech, to dzień życia minionego...

Nie padnie pod Twych rąk karanie -

A chwile me do końca biegną...

Jakże mię karać będziesz, Panie? ${ }^{11}$

Warto przede wszystkim zwrócić uwagę na kształt, jaki przybrały owe myśli, kierowane, wszak jeszcze z młodopolskimi akcentami, do Pana wszelkiego stworzenia. Można by żartobliwie powiedzieć, iż jest to jedna z najbardziej teologicznych form poetyckich, której budowa w pełni odzwierciedla istotę Boga w Trójcy Jedynego. Są więc tercyny doskonałym dowodem na niezwykle silną potrzebę zanurzenia opisywanego świata w myśl kształtującą przez wieki oblicze kultury i cywilizacji europejskiej, w myśl chrześcijańską. O ile bowiem w Wahadle Staff sugeruje jedynie możliwe rozwiązania, o tyle pojawiające się w tym tekście pojęcia grzechu, kary, sądu ostatecznego, jednoznacznie wskazują na źródła jego myślenia. A są to intuicje godne zastanowienia, chociażby poprzez wage spraw, które znalazły się w obszarze ich przepowiadania ${ }^{12}$.

Najbardziej widoczną tezą, stanowiącą zarazem punkt wyjścia do dalszych rozważań podmiotu lirycznego, jest ta o niemożności konsekwentnego przyję-

\footnotetext{
11 Leopold Staff, Zmierzch winy, w: Dzień duszy, op. cit., s. 77-78.

12 Odnośnie tercyn jeszcze: specyficzny układ rymów (aba, bcb, cdc itd.) przywodzi także na myśl, poprzez swe wzajemne przeplatanie się, te fragmenty teodycei, w których uznając nieuchronność powiązania ze sobą dobra i zła (zło jako nieobecność dobra lub zło jako odwrotna, konieczna strona bytu) próbowano dowieść nieuniknionego zwycięstwa Dobrej Nowiny. Por. także: Gdzie jednak wzmógł się grzech, tam jeszcze obficiej wylała się laska, aby jak grzech zaznaczył swoje królowanie nad śmiercia, tak laska przejawiła swe królowanie przez sprawiedliwość, wiodaca do życia wiecznego przez Jezusa Chrystusa, Pana naszego (Rz 5, 20).
} 
cia prawa przemijalności bez rozciągnięcia stopnia jego oddziaływania na całą rzeczywistość stworzoną, w tym na rzeczywistość grzechu i ułomności ludzkiej. Już w pierwszej strofie wiersza pojawia się znaczące nawiązanie do poprzednio omawianego tekstu: Gdy zegar dni mych bić przestanie. Zarazem treść otwierającego Zmierzch winy pytania stawia daleko idące zastrzeżenia, których istotę staraliśmy się okazać na przykładzie Wahadła. Przypomnijmy jednak raz jeszcze główną ich myśl: przemijalność prowadzi, i ukazuje zarazem, nieuchronność objawienia się wieczności, dlatego też możliwe jest ich wzajemne, dopełniające się współistnienie. Idzie więc teraz o to, by na podstawie tak przyjętych przesłanek móc cokolwiek o tej wieczności powiedzieć. Jednak zauważmy, jak konsekwentnie pogląd ten został przywołany już w pierwszych wersach utworu: Jakże mnie karać będziesz Panie / Za grzechy moje i za winy? Kiedy zatem wypełni się czas, a zegar dni mych bić przestanie, kiedy to wszystko osiągnie sobie właściwy kres, moment śmierci... to nie jest koniec! Następuje bowiem, zaraz, tuż po nim, akt przeniesienia dotychczasowej egzystencji w nowe, pełniejsze ramy, który jest zarazem aktem decydującym o kształcie objawiającej się wieczności - i tu właśnie zaczyna się stawiany przez Staffa problem.

W jakiż więc sposób minione dnie, które wydają się z perspektywy duszy, obejmowanej już wszechwładnymi ramionami ostateczności, tylko snami z głębin: W nicość rozprzegłe, próżne czasze / Niegdyś miodnymi skrzace plyny, w jaki więc sposób mają znowu zostać powołane do życia i osądzone? Przecież to dzięki wszystko ogarniającemu prawu czasu i przemijania człowiek mógł wyzbyć się na tyle swej doczesności, by stanąć wreszcie twarzą w twarz ze swym Stwórcą. Jakże teraz Pan mógłby, przecząc samemu sobie, odwracać swoje prawa przeciw swoim sługom? Przecież to z Jego woli: Przewiny nasze, grzechy nasze / To dnie trawione swemi żary, / Á̇ mrok nicości je opasze.

Dochodzimy w tym momencie do myśli kluczowej. Otóż odpowiedź, którą daje Staff, jest oczywista: w naszym myśleniu o przemijalności, wieczności i sądzie ostatecznym natrafiamy na kolejny paradoks. I o ile w Wahadle była to sprzeczność pozorna, której zauważenie niejako dopełnia oglądu rzeczywistości jako spójnej i wielowymiarowej, o tyle istnienie drugiej domaga się całkowitego odrzucenia. Cóż nam wtedy pozostanie?

Pozostanie nam uznać, iż wraz z odejściem każdej z chwil umierają także nasze grzechy; iż dobry Bóg znacząc Swe nieposłuszne stworzenie piętnem przemijalności, wystarczająco je już ukarał, a prawdziwe chrześcijańską postawą będzie nie rozpaczliwa próba zachowania swojego życia, ale raczej pogodnego przyjęcia losu, który w każdym najdrobniejszym momencie i ciężarze swego trwania zapowiada ostateczne usprawiedliwienie. Wszak Każdy grzech w sobie ma rdzen kary - / A kara grzechom to ich zgłada... 
Należałoby jeszcze zapytać: czy twierdzić można tak z całą pewnością? I to pytanie musi pozostać bez odpowiedzi, o ile bowiem rozum nasz łatwo wykrywa sprzeczność, o tyle musi, z drugiej strony, przyjąć warunek konieczny ograniczoności sądów i możliwości naszego poznania. Można więc zatem powtórzyć, w nadziei, że nasze intuicje okażą się trafne, za młodym wówczas poetą: Nie stanie grzech mój pod Twym biczem, / Bo niema już dnia grzechu mego. / Przewina moja jest dziś niczem... / Grzech, to dzień życia minionego... / Nie padnie pod Twych rak karanie - / A chwile me do końca biegna...; by za chwilę zapytać: Jakize mie karać będziesz, Panie?

Ostatecznie jednak to słowa dojrzałego już Staffa, stojącego na samym progu wieczności, wypowiedziane u zmierzchu jego życia, rozpiętego w tym czasie między dwie rzeczywistości, z których żadna jeszcze nie przeważa, kiedy więc słońce jeszcze nie zaszło, a noc nie rozpoczęła swojego panowania, pasują tu najbardziej:

Problemów się nie rozwiązuje. Problemy się przeżywa... ${ }^{13}$

Tymi dwoma tekstami, pochodzącymi ze zdumiewającego swą przenikliwością Dnia duszy, próbował młody poeta zmierzyć się z pytaniem szczególnym, pytaniem o sens ludzkiej śmierci i przemijalności. Nie sposób jednak nie zauważyć, że odnaleziona przezeń odpowiedź, zawarta w poetyckich frazach Wahadta oraz Zmierzchu winy, z góry naznaczyła dalszą drogę jego duchowego i artystycznego rozwoju. Tym samym Staffowe rozważania o rzeczach ostatecznych, niosąc w swych wierszach pogodną nadzieję, stały się świadectwem najpiękniejszego bo wyartykułowanego w postawie całkowitej ufności - Credo polskiego, jasnego klasycyzmu.

13 Leopold Staff, Dziewięć muz, PIW, Warszawa 1958, s. 55. 